\title{
Analisa dan Perancangan Sistem Informasi Pengarsipan Berkas Pertanggungjawaban Anggaran APBD pada Dinas Pemuda dan Olahraga Provinsi Kepulauan Bangka Belitung
}

\author{
Fico Setiawan \\ Sistem Informasi STMIK Atma Luhur Pangkalpinang \\ Jl. Jend. Sudirman, Selindung, Pangkalpinang \\ Kepulauan Bangka Belitung \\ fhico25@gmail.com
}

\author{
Elly Yanuarti \\ STMIK Atma Luhur \\ Jl. Jend. Sudirman, Selindung, Pangkalpinang \\ Kepulauan Bangka Belitung \\ elly@atmaluhur.ac.id
}

\begin{abstract}
Abstrak - Sistem pengelolaan arsip memegang peranan penting bagi jalannya suatu organisasi yang dapat bermanfaat sebagai sumber informasi yang dapat dijadikan bahan penilaian dan pengambilan keputusan untuk penyusunan program pengembangan organisasi. Pengarsipan berkas pertanggungjawaban anggaran belanja derah yang dilakukan di Dinas Pemuda dan Olahraga Provinsi Kepulauan Bangka Belitung belum begitu baik dimana sering terjadi kehilangan berkas dan tidak pernah dilakukan backup data sehingga berkas harus dibuat ulang. Untuk itu dirasakan perlu adanya sebuah sistem informasi yang dapat membantu mengatasi permasalahan yang ada. Analisa dan perancangan sistem dalam penelitian ini menggunakan metode berorientasi objek dengan pemodelan UML dan menggunakan tools Rational Rose. Penelitian ini menghasilkan desain sistem informasi pengarsipan yang mampu menghasilkan informasi yang cepat dan akurat bagi pengambilan keputusan.
\end{abstract} UML.

Kata Kunci : Sistem Informasi, Sistem Informasi Pengarsipan,

\section{PENDAHULUAN}

Perkembangan dan kemajuan teknologi saat ini, semua instansi baik pemerintahan atau swasta dituntut dapat menyesuaikan dengan perkembangan teknologi supaya informasi dapat diperoleh secara tepat, cepat, dan akurat. Instansi yang didukung dengan sistem komputer, maka kontrol dan audit atas komputer sangat dibutuhkan untuk menjaga integritas data suatu instansi. Dalam memproses data pada suatu instansi jika tidak dikontrol dengan baik, maka dapat terjadi penyalahgunaan atau penyelewengan oleh pihak yang tidak bertanggung jawab. Suatu instansi akan terlihat lebih terorganisasi jika menggunakan sistem informasi dalam melakukan semua kegiatan.

Dinas Pemuda dan Olahraga Provinsi Kepulauan Bangka Belitung merupakan suatu instansi yang berperan penting dalam meningkatkan atlet-atlet handal di Provinsi Bangka Belitung agar dapat bersaing dengan atlet-atlet provinsi lainnya. Dalam melaksanakan kegiatan terutama bidang olahraga, instansi ini menggunakan dana APBD. Saat ini Dinas Pemuda dan Olahraga dalam melakukan pengelolaan berkas pertanggungjawaban anggaran APBD belum memanfaatkan komputer secara optimal termasuk dalam pengarsipannya. Pengarsipan berkas pertanggungjawaban belanja daerah merupakan faktor yang menentukan pengurangan nilai kekayaan bersih dan merupakan batas tertinggi untuk setiap jenis belanja yang bersangkutan. Permasalahan yang sering terjadi pada instansi tersebut adalah kesulitan melakukan pencarian dokumen kegiatan pada saat terjadi pemeriksaan oleh Inspektorat, BPK, serta pihak - pihak terkait mengenai berkas pertanggungjawaban anggaran APBD. Hal tersebut terjadi karena adanya berkas yang hilang karena berkas tidak tersimpan dengan rapi dan tidak di backup. Oleh karena tidak ada backup data maka berkas harus dibuat ulang. Padahal pemerintah sangat membutuhkan informasi yang cepat dan akurat sebagai landasan pengambilan keputusan untuk membangun daerah. Berdasarkan permasalahan diatas maka diperlukan sebuah sistem informasi pengarsipan berkas pertanggungjawaban anggaran APBD yang mampu mengolah data dengan cepat dan menghasilkan informasi yang akurat untuk pengambilan keputusan.

\section{TINJAUAN PUSTAKA}

\section{A. Definisi Sistem}

Sistem adalah suatu jaringan kerja dari prosedur-prosedur yang saling berhubungan, berkumpul bersama untuk melakukan suatu kegiatan atau untuk menyelesaikan suatu sasaran tertentu[1] 


\section{B. Definisi Sistem Informasi}

Informasi adalah data yang telah diproses atau disusun ke dalam suatu format lebih berarti untuk seseorang. informasi dibentuk dari kombinasi dari data yang dengan penuh harapan dapat mempunyai arti bagi penerimanya [1].

Kualitas informasi tergantung dari tiga hal yaitu informasi yang dihasilkan harus [2]:

\section{Akurat (Accuracy)}

Sebuah informasi dapat dikatakan akurat jika informasi tersebut tidak bias atau menyesatkan, bebas dari kesalahan-kesalahan dan harus jelas mencerminkan maksudnya.

\section{Tepat Waktu (Timeliness)}

Informasi yang dihasilkan dari suatu proses pengolahan data yang diberikan harus tepat waktunya, tidak terlambat karena informasi merupakan landasan dalam pengambilan keputusan. Informasi yang terlambat tidak akan mempunyai nilai yang baik, sehingga kalau digunakan sebagai dasar dalam pengambilan keputusan dapat menimbulkan kesalahan dalam tindakan yang diambil. Kebutuhan akan tepat waktunya sebuah informasi itulah yang pada akhirnya akan menyebabkan mahalnya nilai suatu informasi.

\section{Relevan (Relevancy)}

Informasi akan relevan jika memberikan manfaat bagi pemakainya dan sesuai dengan kebutuhan, serta berkaitan langsung dengan masalah yang ada.

Pendekatan definisi sistem berdasarkan pendekatan prosedur adalah Sistem adalah kumpulan dari prosedurprosedur yang mempunyai tujuan-tujuan tertentu [5].

Sistem Informasi dapat diartikan sebagai suatu susunan dari orang, data, proses, dan teknologi informasi yang saling berkaitan untuk mengumpulkan, memproses, menyimpan, dan menyediakan keluaran informasi yang dibutuhkan untuk mendukung suatu organisasi [6].

\section{Unfied Modelling Language (UML)}

UML merupakan salah satu alat bantu yang sangat handal di dunia analisa dan perancangan sistem informasi yang berorientasi obyek (Object Oriented). Hal ini disebabkan karena UML menyediakan bahasa pemodelan visual yang memungkinkan bagi pengembang sistem untuk membuat cetak biru (Blue Print) atas visi mereka dalam bentuk yang baku, mudah dimengerti serta dilengkapi dengan mekanisme yang efektif untuk berbagi (sharing) dan mengkomunikasikan rancangan mereka dengan yang lain [4].

Berberapa diagram UML yang digunakan dalam penelitian ini antara lain :

\section{Activity Diagram}

Activity diagram digunakan untuk menggambarkan alur kerja (work flow) sebuah proses bisnis dan urutan aktivitas pada suatu proses. Activity diagram menggambarkan aktivitas dari aktor[3]

\section{Use Case Diagram}

Use case diagram menggambarkan sebuah fungsionalisme yang diharapkan dari sebuah sistem dan bagaimana sistem berinteraksi dengan dunia luar[3]

\section{Class Diagram}

Class Diagram adalah sebuah spesifikasi yang jika diinstanisasi akan menghasilkan sebuah objek dan merupakan inti dari pengembangan dan desain berorientasi objek . Class menggambarkan keadaan (atribut/properti) suatu sistem sekaligus menawarkan layanan untuk memanipulasi keadaan tersebut (metode/fungsi). Class diagram menggambarkan struktur dan deskripsi class, package, dan objek beserta hubungan satu sama lain seperti containment, pewarisan, asosiasi dan lain-lain.[3]

\section{METODE PENELITIAN}

\section{A. Metode Pengumpulan Data}

\section{1) Observasi}

Meninjau dan mengunjungi langsung ke Dinas Pemuda dan Olahraga Provinsi Kepulauan Bangka Belitung untuk mengetahui secara keseluruhan tentang masalah yang akan dibahas.

\section{2) Wawancara}

Wawancara langsung dengan pihak-pihak yang berkepentingan untuk mengumpulkan data - data yang dibutuhkan.

\section{3) Studi Kepustakaan}

Mengumpulkan teori-teori yang relevan dengan masalah yang dibahas melalui buku - buku di perpustakaan.

\section{B. Analisa Sistem}

Salah satu pendekatan pengembangan sistem adalah pendekatan analisa berorientasi objek. Pendekatan berorientasi objek dilengkapi dengan alat-alat teknik pengembangan sistem yang hasil akhirnya akan didapat sistem yang didefinisikan dengan baik dan jelas. Kegiatan yang dilakukan pada tahap ini adalah :

1. Menganalisa sistem yang ada, yaitu mempelajari dan mengetahui apa yang dikerjakan sistem yang ada.

2. Menspesifikasikan sistem, yaitu menspesifikasikan masukan yang digunakan, database yang ada, proses yang dilakukan dan keluaran yang dihasilkan.

Dalam melakukan analisa digunakan pemodelan UML. Salah satu diagram UML yang digunakan dalam penelitian ini adalah Activity Diagram untuk menggambarkan proses dari sistem yang sedang berjalan. 


\section{Perancangan Sistem}

Tahap Perancangan Sistem adalah merancang sistem secara rinci berdasarkan hasil analisa sistem yang ada, sehingga menghasilkan model sistem baru yang diusulkan, dengan disertai rancangan database.

Alat bantu untuk memodelkan sistem yang diusulkan adalah diagram UML yaitu Use Case Diagram dan Class Diagram.

\section{HASIL DAN PEMBAHASAN}

\section{A. Analisa Sistem Yang Berjalan}

Berikut ini adalah gambaran proses / prosedur yang dilakukan Dinas Pemuda dan Olahraga Provinsi Kepulauan Bangka Belitung pada sistem yang sedang berjalan :

1. DPPKAD menyerahkan Dokumen Pelaksanaan Anggaran (DPA) ke DISPORA dan kemudian bagian pengarsipan mencatatnya kedalam buku Register.

2. Kepala Bidang selanjutnya menyerahkan SK Pejabat Pelaksana Teknis Kegiatan (PPTK) ke bagian pengarsipan, dan dicatat ke dalam buku register. Bagian pengarsipan kemudian menyerahkan Dokumen DPA dan SK PPTK tersebut kepada PPTK.

3. Berdasarkan anggaran kegiatan belanja Dinas Pemuda dan Olahraga, PPTK membuat kartu kendali dan menyerahkan kartu kendali ke bagian pengarsipan, yang selanjutnya dicatat ke buku register.

Proses kegiatan diatas dapat digambarkan kedalam sebuah activity diagram seperti berikut :

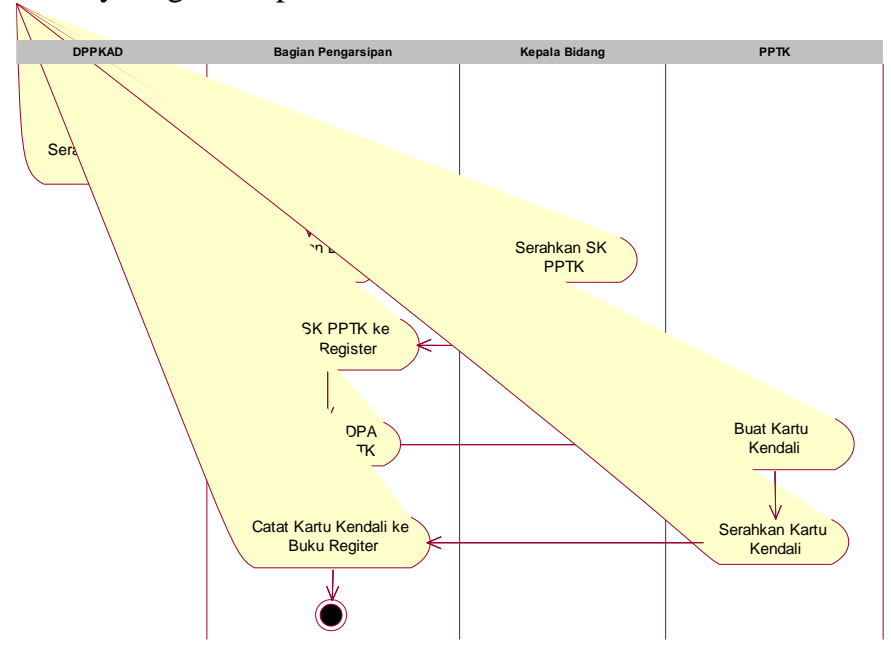

Gambar 1. Activity Diagram

\section{B. Use Case Diagram}

Use case diagram digunakan untuk menggambarkan kebutuhan dan fungsionalitas sistem dari sudut pandang user.
Berikut ini adalah use case diagram dari sistem yang diusulkan antara lain :

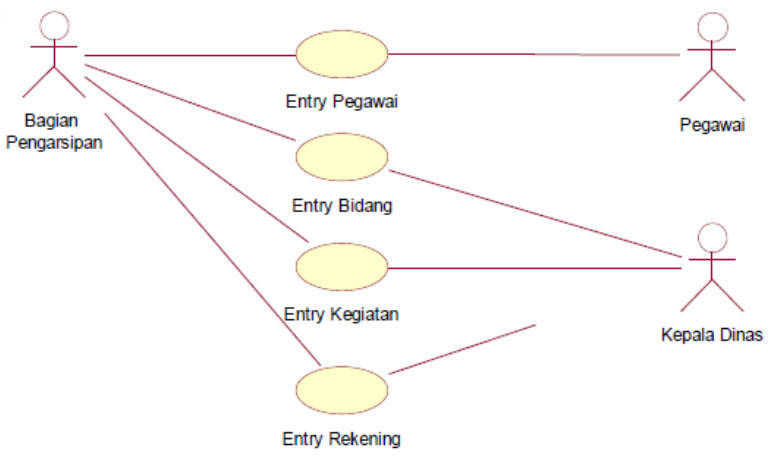

Gambar 2. Use Case Diagram Pendataan

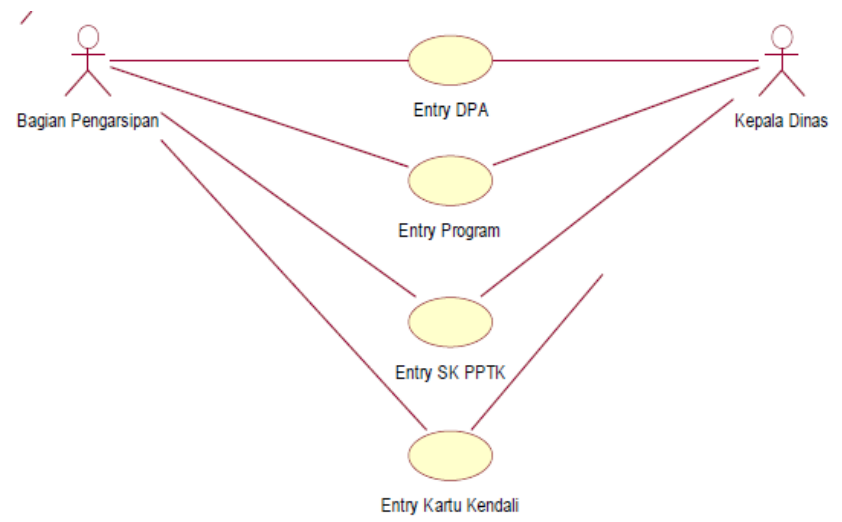

Gambar 3. Use Case Diagram Transaksi

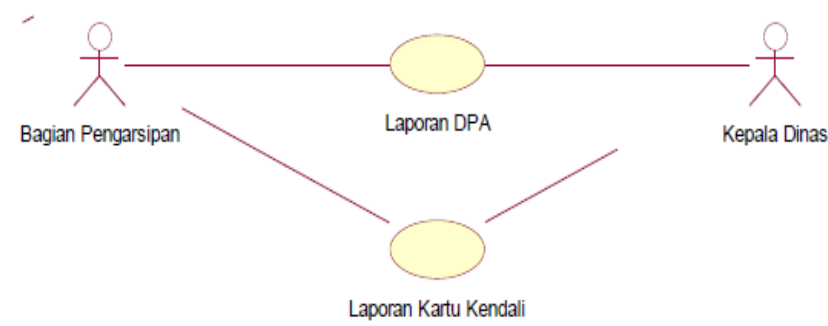

Gambar 4. Use Case Laporan

\section{Rancangan Basis Data}

Basis data merupakan komponen utama sistem informasi karena semua informasi untuk pengambilan keputusan berasal dari data yang ada di basis data. Rancangan basis data digambarkan dalam bentuk Logical Record Structure (LRS) seperti berikut : 


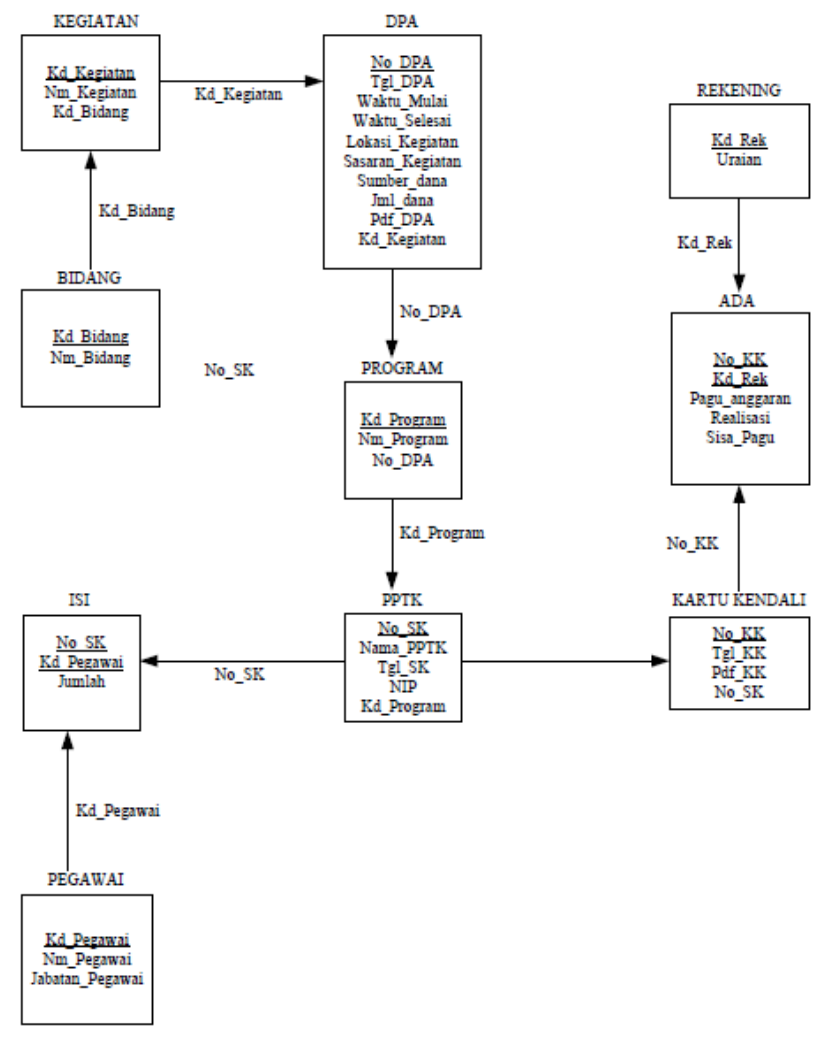

Gambar 5. Logical Record Structure

Berdasarkan gambar LRS diatas maka terbentuklah tabel yang dibutuhkan untuk sistem yang baru antara lain :

1. Tabel Pegawai

Tabel 1. Tabel Pegawai

\begin{tabular}{|c|c|c|}
\hline Kd_Pegawai & Nm_Pegawai & Jabatan_Pegawai \\
\hline PK & & \\
\hline
\end{tabular}

2. Tabel Bidang

Tabel 1. Tabel Bidang

\begin{tabular}{|c|c|}
\hline Kd_Bidang & Nm_Bidang \\
\hline PK & \\
\hline
\end{tabular}

3. Tabel Kegiatan

Tabel 1. Tabel Kegiatan
\begin{tabular}{|c|c|c|}
\hline Kd_Kegiatan & Nm_Kegiatan & Kd_Bidang \\
\hline PK & & FK \\
\hline
\end{tabular}

\section{Tabel DPA}

Tabel 1. Tabel DPA

\begin{tabular}{|c|c|c|c|c|}
\hline No_DPA & Tg1_DPA & Waktu_Mulai & Waktu_Selesai & Lokasi_Kegiatan \\
\hline PK & & & & \\
\hline
\end{tabular}

\begin{tabular}{|c|c|c|c|c|}
\hline Sasaran_Kegiatan & Sumber_Dana & Jml_Dana & Pdf_DPA & Kd_Kegiatan \\
\hline & & & & FK \\
\hline
\end{tabular}

\section{Tabel Program}

Tabel 1. Tabel Program

\begin{tabular}{|c|c|c|}
\hline Kd_Program & Nm_Program & No_DPA \\
\hline PK & & FK \\
\hline
\end{tabular}

\section{Tabel PPTK}

\begin{tabular}{|c|c|c|c|c|}
\hline No_SK & Nama_PPTK & Tgl_SK & NIP & Kd_Program \\
\hline PK & & & & FK \\
\hline
\end{tabular}

7. Tabel Isi

\begin{tabular}{|c|c|c|}
\multicolumn{3}{|c|}{ Tabel 1. Tabel Isi } \\
\hline No_SK & Kd_Pegawai & Jumlah \\
\hline PK & PK & \\
\hline \multicolumn{2}{|c|}{ FK } & \\
\hline
\end{tabular}

8. Tabel Rekening

Tabel 1. Tabel Rekening
\begin{tabular}{|c|c|}
\hline Kd_Rek & Uraian \\
\hline PK & \\
\hline
\end{tabular}

9. Tabel Ada

\begin{tabular}{|c|c|c|c|c|}
\hline \multicolumn{7}{|c|}{ Tabel 1. Tabel Ada } \\
\hline No_KK & Kd_Rek & Pagu_Anggaran & Realisasi & Sisa_Pagu \\
\hline PK & PK & & & \\
\hline \multicolumn{2}{|c|}{ FK } & & & \\
\hline
\end{tabular}

\section{Tabel Kartu Kendali}

\begin{tabular}{|c|c|c|c|}
\hline \multicolumn{4}{|c|}{ Tabel 1. Tabel Kartu Kendali } \\
\hline No_KK & Tgl_KK & Pdf_KK & No_SK \\
\hline PK & & & FK \\
\hline
\end{tabular}

\section{Rancangan Layar}

Berikut ini adalah tampilan desain form yang digunakan untuk melakukan pengolahan data oleh user yang dalam hal ini adalah bagian kepegawaian.

\section{Form Entry Pegawai}

Form ini digunakan untuk mengolah data pegawai seperti dapat melakukan penambahan data pegawai, mengubah maupun menghapus data pegawai.

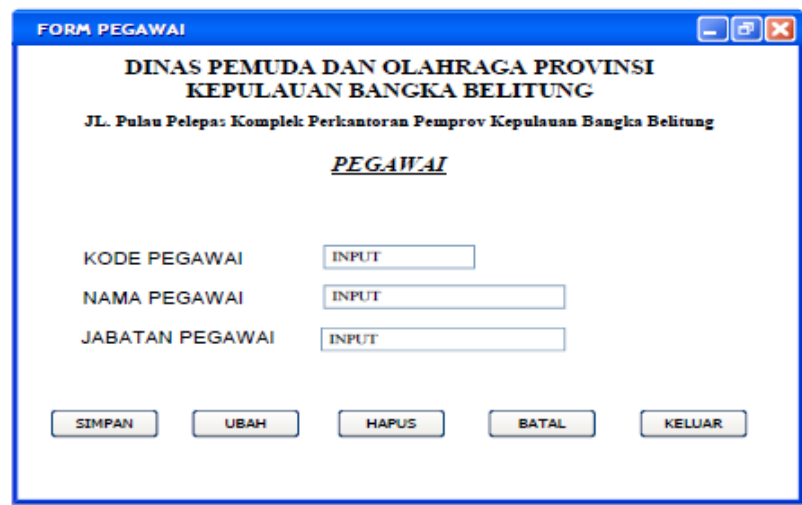

Gambar 6. Rancangan Layar Entry Pegawai

\section{Form Entry Bidang}

Form ini digunakan untuk melakukan pengolahan data bidang dalam kegiatan. User dapat melakukan penambahan data bidang, mengubah maupun menghapus data bidang. 


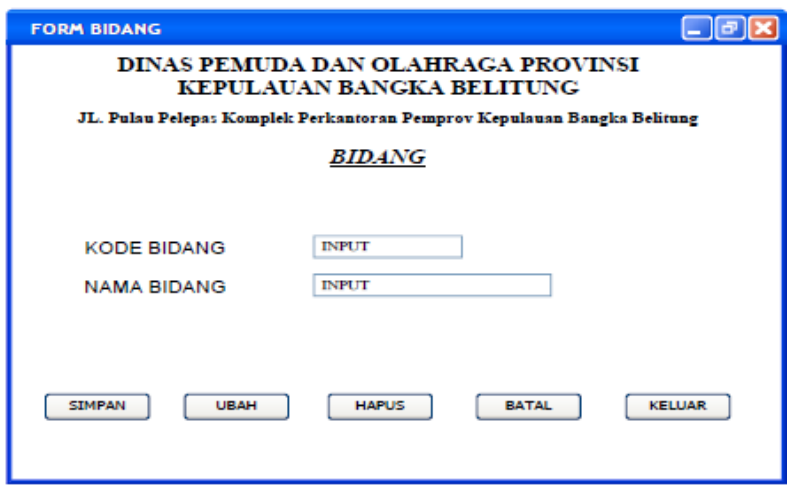

Gambar 7. Rancangan Layar Entry Bidang

\section{Form Entry Kegiatan}

Form ini digunakan untuk melakukan pengolahan data kegiatan. User dapat melakukan penambahan data kegiatan, mengubah maupun menghapus data kegiatan.

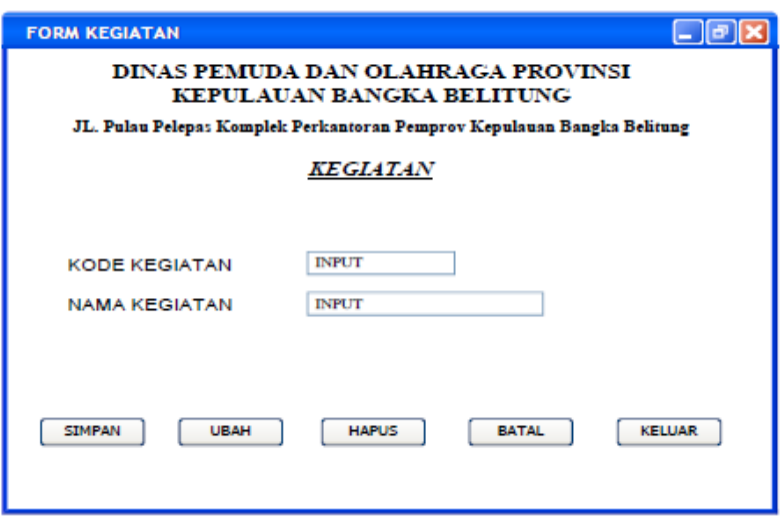

Gambar 8. Rancangan Layar Entry Kegiatan

\section{Form Entry Rekening}

Form ini digunakan untuk melakukan pengolahan data rekening yang digunakan dalam kegiatan. User dapat melakukan penambahan data rekening, mengubah maupun menghapus data rekening.

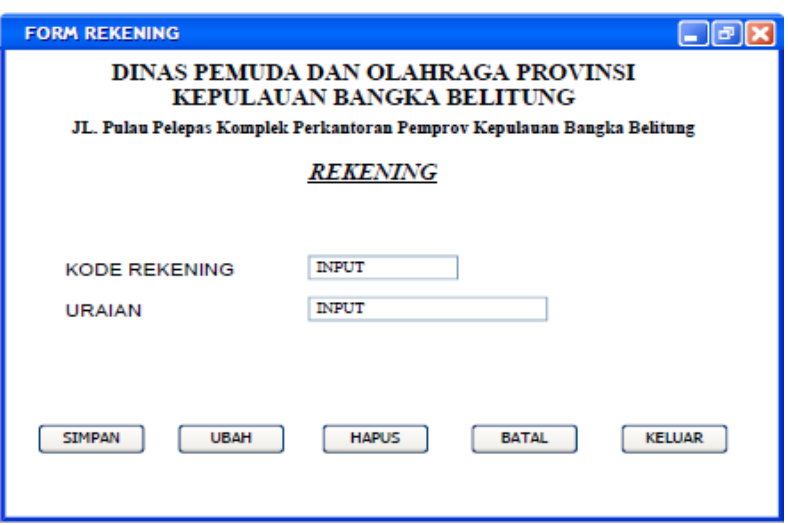

Gambar 9. Rancangan Layar Entry Rekening
Jurnal SISFOKOM, Volume 05, Nomor 01, Maret 2016

\section{Form Entry DPA}

Form ini digunakan untuk melakukan pengolahan data Dokumen Pelaksanaan Anggaran (DPA) yang berisi data kegiatan seperti waktu pelaksanaan kegiatan dan dananya.

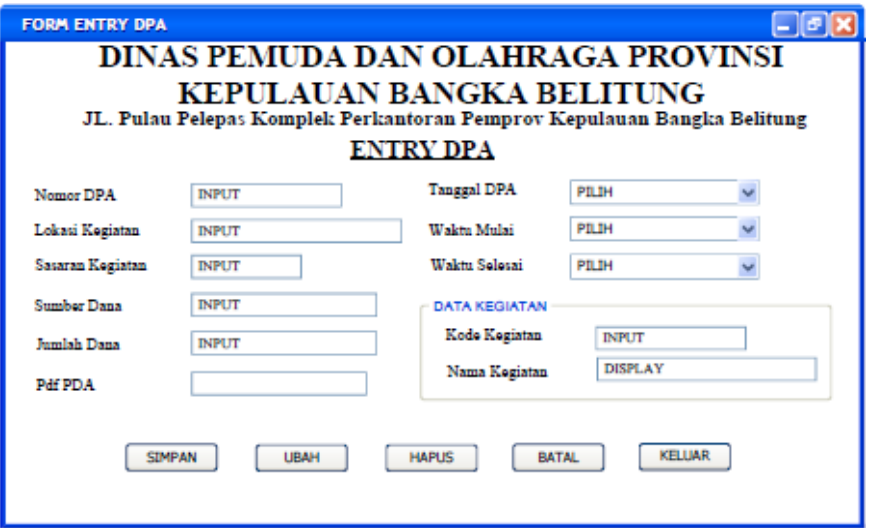

Gambar 10. Rancangan Layar Entry DPA

\section{Form Entry Program}

Gambar 11 adalah tampilan desain form yang digunakan untuk melakukan pengolahan data program dan DPA.

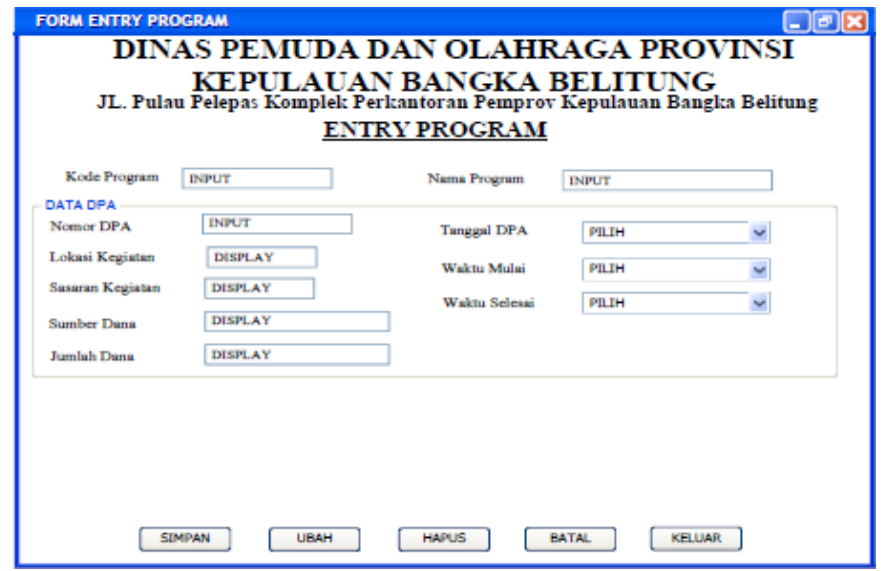

Gambar 11. Rancangan Layar Entry Program

\section{Form Entry SK PPTK}

Gambar 12 dibawah ini merupakan tampilan desain form yang digunakan untuk melakukan pengolahan data SK PPTK yang berisi tentang data pegawai dan program. 


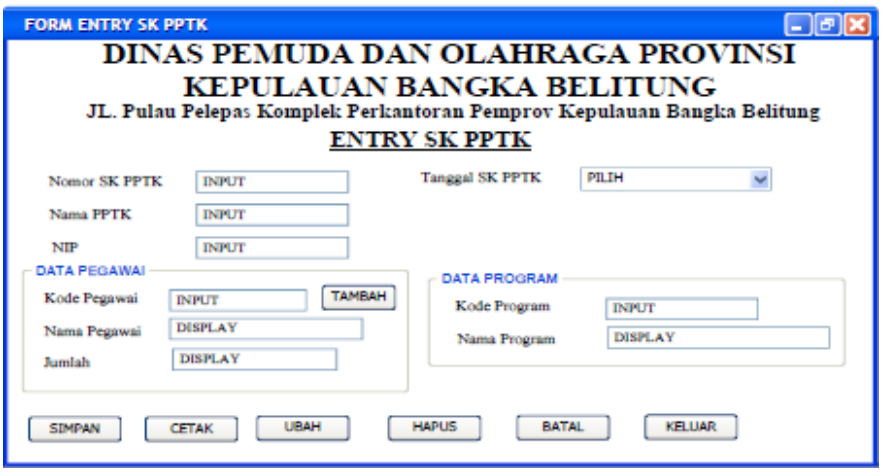

Gambar 12. Rancangan Layar Entry SK PPTK

\section{Form Entry Kartu Kendali}

Gambar 13 merupakan tampilan desain form yang digunakan untuk melakukan pengolahan data Kartu Kendali yang berisi tentang data kegiatan, data rekening dan data SK PPTK. User juga dapat melakukan pencetakan kartu kendali.

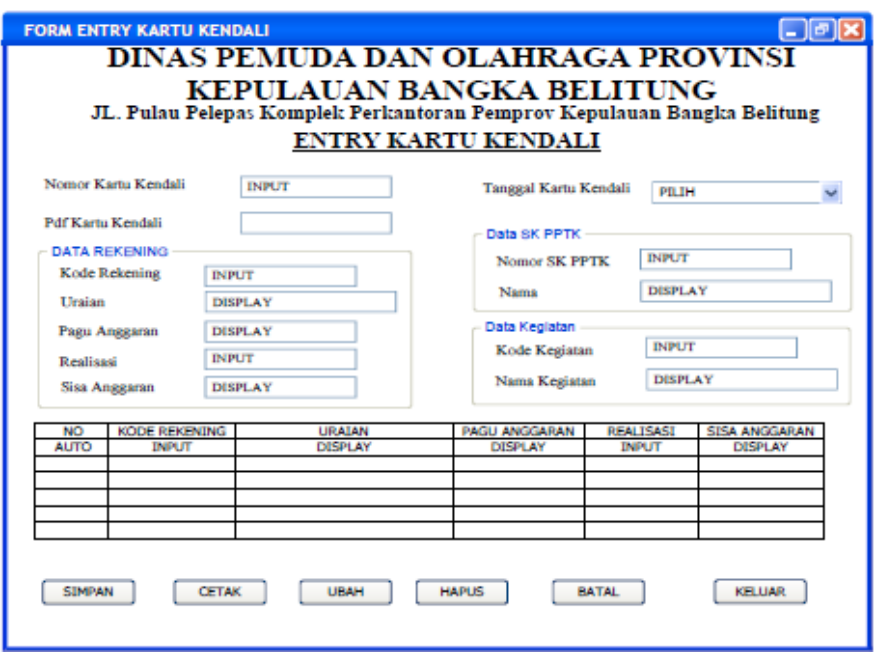

Gambar 13. Rancangan Layar Entry Kartu Kendali

\section{E. Class Diagram}

Dibawah ini adalah gambar class diagram yang menunjukkan aliran sistem informasi dari sistem yang baru :

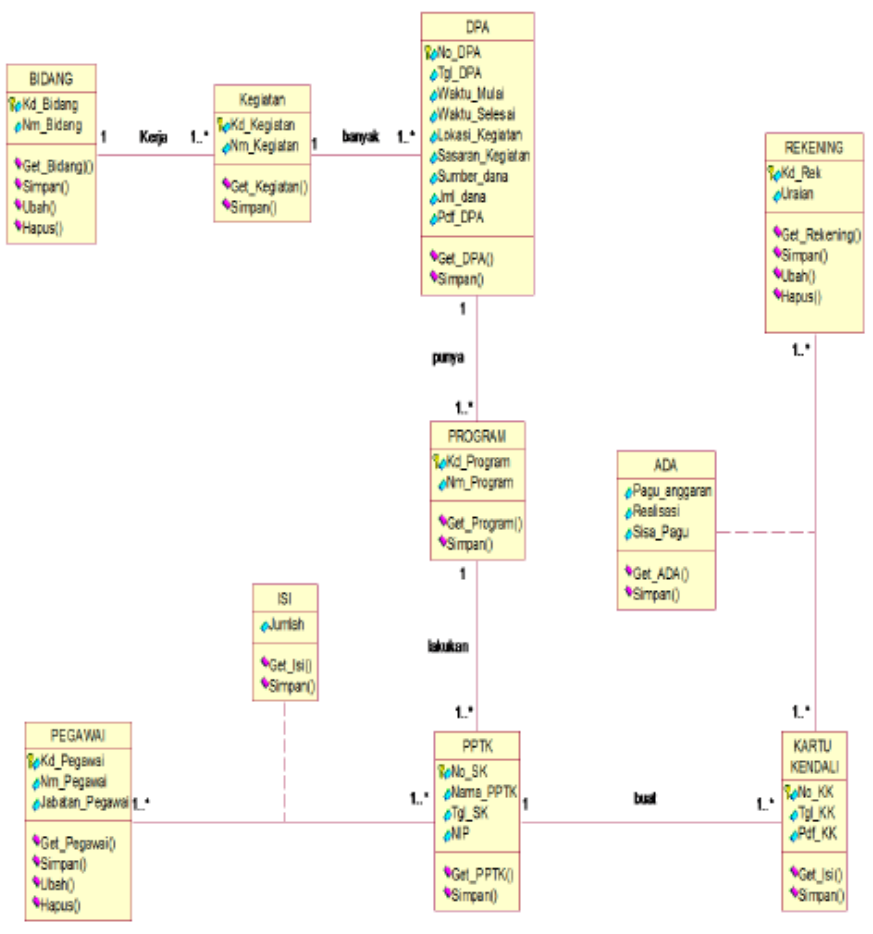

Gambar 13. Class Diagram

\section{PENUTUP}

Kesimpulan yang dapat diambil dari penelitian ini adalah sebagai berikut :

1. Rancangan sistem yang terkomputerisasi dapat membantu khususnya bagian pengarsipan dalam mengolah data pertanggungjawaban anggaran menjadi lebih efektif dan efisien.

2. Penyimpanan data dalam basis data yang terkomputerisasi akan meminimalkan akses kepada data fisik atau arsip. Dengan demikian data atau informasi akan tersimpan dengan aman dan dapat diakses lebih cepat.

3. Dengan menggunakan sistem terkomputerisasi maka pembuatan laporan-laporan dapat dilakukan dengan mudah dan cepat serta menghasilkan informasi yang lebih akurat.

\section{DAFTAR PUSTAKA}

[1] Whitten, Jeffery L, et al. Sistem Analysis and Design Methods. New York : McGraw-Hill/Irwin, 2004.

[2] Jogiyanto, Hartono. Analisis \& Design Sistem Informasi Pendekatan Terstruktur Teori dan Praktek Aplikasi Bisnis. Yogyakarta : Andi, 2005.

[3] Munawar, Ahmad. Pemodelan Visual Dengan UML Jakarta : Graha Ilmu, 2005. 
[4] Munawar, Ahmad. Pemodelan Visual Dengan UML. Jakarta : Graha Ilmu, 2005.

[5] Sutopo, Aristo Hadi. Analisis Dan Desain Berorientasi Objek. Jakarta : J\&J Learning. Yogyakarta, 2002.

[6] Schwalbe, Katty. Managing Information Technology Projects. Canada : Course Technology, 2004. 